\title{
Presencias del modernismo en la primera vanguardia histórica argentina: las reescrituras y apropiaciones de Nicolás Olivari
}

\author{
Sara Amalia BOSOER \\ Universidad Nacional de La Plata
}

\begin{abstract}
RESUMEN
La presencia del modernismo y de la literatura de Darío era notoria en la cultura popular urbana argentina de la década del 1920. Este trabajo estudia los diálogos que establece en ese período la literatura de Nicolás Olivari (1900-1966), un poeta de la primera vanguardia histórica, con dicha estética. Detenerse en estas apropiaciones, especialmente las efectuadas en sus primeros textos, permite revisar su poética y explicar uno de los modos en que se produjo una manifestación vanguardista.
\end{abstract}

Palabras clave: vanguardias, modernismo, Nicolás Olivari, Rubén Darío, década de1920, cultura popular.

Presences of modernism in the Argentine literary avant-garde from 1920th decade: rewriting and appropriations of Nicolás Olivari

\begin{abstract}
The presence of modernism and literature of Dario was notorious in the Argentine urban popular culture of the 1920s. This paper studies the dialogues that the literature of Nicolás Olivari (1900-1966), one of the poets of the first historical avant-garde, sets in its context of production. Pay attention to its appropriation, especially in his early writings, can review his poetry and explain one of the modes in which occurs a vanguard manifestation.
\end{abstract}

Key words: Avant-garde, Modernism, Nicolás Olivari, Rubén Darío, 1920 decade, Popular culture.

Cuando en la década de 1920, emerge lo que se dio en llamar "la primera vanguardia histórica argentina", la estética dominante en el circuito ampliado de la cultura -esto es, en el circuito de producción y consumo que incluye al gran público, al creciente mercado editorial, a la prensa y a las instituciones escolares- era la de matriz modernista, junto con sus diversas manifestaciones epigonales, el romanticismo y el tardo romanticismo (Sarlo 1999). Se trataba de una etapa de cambios culturales profundos, estrechamente vinculados con la extensión del espacio literario, con la influencia de la inmigración y el proceso de alfabetización masiva, entre otras características asociadas a la modernización y a la 
democratización cultural. Este proceso de expansión incluye la emergencia de figuras de escritor que resultan novedosas por su procedencia social y porque construyen modos diversos de los tradicionales para relacionarse con la cultura letrada. Se trata, en su mayoría, de los hijos de inmigrantes alfabetizados en las escuelas públicas, que integraban las capas populares y en ascenso de la sociedad. Estos jóvenes inician su vida literaria en los años del 1920, al mismo tiempo que escritores como Borges o Girondo, quienes en cambio, tuvieron acceso a colegios europeos o a surtidas bibliotecas familiares. Por su parte, Nicolás Olivari (19001966), al igual que contemporáneos suyos como Roberto Arlt o Raúl González Tunón, era hijo de inmigrantes, en su caso italianos, y como ellos, fue un protagonista de este proceso de ampliación.

Olivari inicia su carrera literaria con la publicación de relatos realistas (los cuentos Carne al sol (1922); las novelas cortas La carne humillada (1922); Historia de una muchachita loca (1923); ;Bésame la boca Mariluisa! (1923)) y vinculado a los escritores de izquierda que en 1924, decanta en la fundación del grupo de Boedo. Esta es una de las formaciones juveniles claves en el período, defensora de un arte comprometido políticamente con el cambio social. Pero a medida que avanzó la década también escribió poesía (La amada infiel (1924); La musa de la mala pata (1926) y El gato escaldado (1929)) y se relacionó con el grupo de Florida, situado en las antípodas del espacio literario. Es así que se inserta en la revista Martín Fierro -que para la historia literaria es sinónimo de la vanguardia- y produce una de las manifestaciones poéticas más radicales del momento, por su carácter antagonista y contestatario de la institución literaria dominante: en consonancia con los desplazamientos que proponen las escrituras de Girondo y de Raúl González Tuñón, Olivari renueva el diccionario poético, incorpora temáticas cuyo estatus literario podía ser problemático, y rompe con la prosodia modernista. Sin embargo, a pesar de que esta apuesta puede describirse sintéticamente en términos similares para los tres poetas, el modo en que cada uno la realiza y los efectos que producen resultan por completo diferentes. En este sentido, estudiar los vínculos que su escritura establece con el modernismo permitirá comprender la profundidad y, sobre todo, los alcances de sus desplazamientos respecto de las convenciones literarias dominantes en el período, y por lo mismo, resulta central para describir su poética.

En esta trama, que evidencia un espacio literario complejo y diverso, la obra de Darío había constituido un horizonte ineludible ${ }^{1}$ para quienes en ese momento, como Olivari, comenzaban a escribir; aunque, por supuesto, las respuestas que elaboraron los escritores jóvenes no son necesariamente coincidentes, dada la heterogeneidad de sus trayectorias y posiciones. Si en el campo nacional, la figura

1 Para la influencia de Darío en Latinoamérica: Zanetti, Susana (1997). Para la divulgación en Argentina a través de la prensa masiva, véase el trabajo de Rogers (2008). 
de Lugones ocupaba un lugar hegemónico, la de Darío estaba disponible, entre otras cosas, como estrategia para ignorar al modernista argentino. Mientras que esta operación resulta especialmente válida para explicar la poética de Girondo, ${ }^{2}$ en el caso de Olivari, además, hay que agregar la necesidad de desplazarse de la lengua poética que hegemonizaba el mercado literario. La difusión que estas estéticas alcanzaban en estos espacios ampliados de circulación y consumo era lo suficientemente considerable como para que un escritor informado sobre esos productos culturales y al mismo tiempo, que aspiraba a conquistar al gran público, pudiese ignorarlos.

En este sentido, reparar en la reelaboración modernista que produce Olivari permite describir uno de los rasgos distintivos de su flexión vanguardista: en sus poesías trabaja con materiales identificados por la cultura del momento con el gusto y las preferencias estéticas de los sectores populares. Pero además, comienza a producir estas elaboraciones desde sus primeras escrituras, es decir que se trata de un desplazamiento vanguardista que se inicia en los títulos inscriptos en el realismo literario y vinculados al espacio ampliado de producción. Habría de esta forma, dos grandes clivajes para leer la escritura de Olivari: la tradición finisecular, especialmente Darío; y las apropiaciones contemporáneas de ese linaje vinculadas al mercado.

Comenzaremos por señalar la relación compleja que la escritura de Olivari establece con el modernismo en tanto se constituye, a la vez, como el modelo de lengua literaria a seguir y como el modelo que debe ser transgredido. Nos detendremos, luego, en las operaciones de apropiación y de reescritura.

\section{Saber escribir: el modernismo, un modelo de lengua escrita}

Una de las cuestiones que resulta posible seguir en las narraciones de la primera etapa es el modo en que se constituye una lengua literaria y el lugar que, aún a comienzos de la década del 1920, ocupaba el modernismo. Como es sabido, su influencia alcanzó a establecer un parámetro de estilo literario: proveía a quienes deseaban escribir, un diccionario y muchas de sus imágenes. En principio, porque conservaba una valorización prestigiosa en el espacio ampliado de la cultura que asociaba varios de sus rasgos a un ideal de literatura alta (Sarlo [1985]2004: 59), cuestión que el joven escritor, con un pasado escolar reciente, no puede obviar o

${ }^{2}$ Para la relación de Girondo con el modernismo, véase (Muschietti: 2009). En este sentido, sobre la vanguardia argentina, Sarlo señaló que "Su intervención en la coyuntura estética se define por la diferencia respecto del modernismo" (Sarlo 1999: 103). Intervención que se sintetiza en la formulación que propone Prieto cuando afirma que "la gran pregunta implícita de la época" era cómo escribir poesía después del Modernismo (Prieto 2006: 365). 
reducir por completo. Adolfo Prieto llamó el "fantasma del estilo" a la presencia de esta matriz modernista en numerosos y diversos escritores del período -como Arlt y Olivari-, que de este modo, buscaban lograr un estatuto literario para sus escrituras.

En este contexto, las primeras narraciones de Olivari producen en diferentes grados, el efecto de una labor de escritura esforzada que se esmera por utilizar un lenguaje y unas formas retóricas "cultas", es decir que pone en primer plano el hecho de que nos encontramos frente a lenguaje escrito. Aquí lo literario es una mezcla -a veces recargada- de adjetivación modernista, imágenes románticas, descripciones que apelan a un diccionario naturalista y expresiones en un castellano escolarizado que por momentos, remeda el tipo de español característico de los económicos libros importados desde la península.

Pero a su vez, el modernismo de Olivari presenta algunas peculiaridades en consonancia con la zona del realismo en que se sitúa. Así, despoja a su escritura de referencias a lujos o refinamientos, ajuste en el que inciden tanto la lectura de Evaristo Carriego como la de Manuel Gálvez; y aunque sí incorpora elementos de la cultura clásica, como veremos más adelante, opera sobre estos usos para descolocarlos de sus sentidos autorizados. En esta dirección, el modernismo posibilitará un movimiento de reescritura que le permitirá a Olivari configurar uno de los rasgos de su lengua: la reflexión sobre sí misma y el humorismo. Como sucedía con muchos de sus contemporáneos, Olivari encuentra en esta literatura una estética productiva, pero anticuada. En sus primeros textos se registra, entonces, una tensión entre el empleo de un diccionario y de recursos que remiten al modernismo y su cuestionamiento.

\section{"Chispean turbados los ojos de Pan"}

Este verso es el último de "Leda" (1892), uno de los poemas en que Rubén Darío construye la imagen del cisne como un símbolo modernista, y fue elegido por Olivari como epígrafe de "Revelación", el cuento que abre Carne al sol. Una cita "antes de comenzar" - advierte Derrida- marca "el tono dejando resonar algunas palabras cuyo sentido o forma deberían dominar la escena" (Derrida 1994: 2). El verso que escoge Olivari (en el que Pan, como una figura traviesa y lasciva, espía desde el "fondo verdoso de fronda tupida" (Darío 1948) la escena erótica entre Leda y el cisne), señala una de las zonas de la escritura donde la impronta modernista resuena con mayor intensidad: la del erotismo. En estas escenas los párrafos se abarrotan de comparaciones y metáforas que a través de descripciones demoradas preparan al lector para el momento culminante. Si estas eran algunas de las convenciones retóricas preferibles para considerar que una lengua era literaria, resulta entonces comprensible su acumulación en escritos que abordaban una temática que fácilmente podía arrojarlos fuera de lo que se pensaba como literatura; 
en este sentido, era clave el desarrollo de esa vertiente erótica desarrollada por los escritos modernistas. ${ }^{3}$

En "Revelación" se puede leer un ejemplo de esta estrategia, probablemente destinada a provocar las fantasías del lector a través del relato de la paulatina incitación del deseo del protagonista:

Ella abrió el nácar de su palma para recibirlo. Las manos chocaron. La de ella, fuerte como una garra de lirios, la suya tímida, temblorosa, como un ala desfalleciente... (13)

Pero al tiempo que la escritura se estetiza en fragmentos como el anterior, cercanos a un lenguaje poético anclado en un diccionario y una simbología reconocibles en los textos del modernismo, Olivari escribe segmentos eróticos directos y explícitos en los que, no obstante, continúa procurando un estilo retórico elaborado a través, por ejemplo, del lenguaje cuidado y de la acumulación de adjetivos:

La artista se estaba desnudando. Un trozo de corpiño, corriéndose hacia abajo, le plantó un seno en el aire. Robusto, henchido, erecto, electrizó la punta mórbida a Julio que se quedó clavado, mudo, casi muerto (12)

Para señalar otro caso, en el cuento "Sol de mediodía", ubicado en un ambiente rural, el espacio pareciera ser tan solo un pretexto para situar la acción erótica, centro de la historia. Se trata de una escena de campo con recargadas descripciones del ambiente y de los personajes que impregnan de erotismo el conjunto del relato, el menos dramático del libro. Luego de arrear las vacas a un corral, Braulio encuentra a Flora lavando la ropa y cantando. La vista de la muchacha mojada despierta -bajo el sol del mediodía- su deseo. Pero hasta que esto ocurre, una larga sucesión de párrafos intensamente estilizados informan lo que sucede en ese paisaje rural: lo que ocurre con la luz, con los sonidos, con los elementos que lo habitan. La selección léxica aproxima estas escrituras a las del modernismo y produce ese efecto de texto literario señalado anteriormente, especialmente en las secuencias descriptivas de paisajes y en las estetizadas presentaciones de personajes:

\footnotetext{
${ }^{3}$ Una de las modalidades que tuvieron estas escrituras eróticas puede seguirse a partir de "Los doce gozos" de Lugones y Los maitines de la noche de Herrera y Reissig. Al respecto, Sarlo afirma que estos títulos "desataron" una "gran ola de sonetos eróticos y perfectos" (Sarlo 1980: 99).
} 
un viento manso ondulaba apenas, casi innotado en la espesa resolana del ambiente, lleno de tierra, que pesaba el aire, puntillándose adamantinamente, coloreada por un rayo igneo (53)

La adjetivación y la acumulación de imágenes contribuyen en este caso, como en el resto de Carne al sol, a la representación simbólica del espacio; así como a la presentación entre animalizada y enaltecida de Braulio: "como un centauro, pegado al tostado nervudo que montaba, pechaba fieramente, cruzando chirlazos sobre los canijos lomos de las vacas" (53). A su vez, las referencias al cuerpo de Flora giran en torno a imágenes plásticas centradas en los efectos que la luz del sol produce sobre su piel mojada: "Gotas de agua y de sudor mezcladas le nimbaban de perlas el tostado rostro, todo lleno de luz como en una transfusión de sol" (55).

Volviendo a "Revelación" - para continuar con las imágenes plásticas- los papeles del "cajoncito de caramelos" de Julio "hacían policromo juego con su cara de manzana madura, de carrillos aterciopelados, como esa fruta, por un vello rubio, muy suave" (7). Por su parte, en "La caída", los tópicos modernistas sirven para una descripción de la protagonista centrada en su vestimenta:

el moño azul en la grácil cintura, que ondeando dulcemente por una ligera brisa remedaba, trémolo ante la dueña, amplio saludo caballeresco de marqués elegante a una reinita del Trianón... (26)

La imaginería modernista aparece, entonces, en descripciones desprovistas de erotismo como las citadas, pero incluidas en relatos que fueron en su conjunto pensados como eróticos. ${ }^{4}$ A su vez, cuando Olivari intensifica la sugestividad -en una búsqueda inversa a la anterior- también recurre al modernismo: "onduló como una pantera las suaves curvas de su caderas, de entre las cuales, el vientre plástico bajo la pollera mojada, semejaba cálida ánfora aguaitando un sumo licor" (55). Esta última comparación pareciera reescribir un verso de Cantar de los cantares: "Tu ombligo es un ánfora redonda, donde no falta el vino". Las referencias a esta tradición como se sabe, proliferan en la literatura de los modernistas y sus derivas argentinas (bastaría mencionar las obras de Almafuerte o de Gerchunoff, como ejemplo) e ingresan en este cuento desde un epígrafe ("Mel et lac sub lingua tua" (53)) que cita un verso también empleado por Darío, y además, reescrito por Olivari; aunque traducido y contextualizado en iBésame la boca Mariluisa! (1923): "Bajo tu lengua, Sulamita, como el Cantar de los Cantares, hay miel y también leche" (19).

\footnotetext{
${ }^{4}$ Así lo declara Olivari en la presentación que escribe para Historia de una muchachita loca (1923).
} 
Este fragmento integra uno de los soliloquios del narrador y refuerza su embeleso ante el paisaje rural y la belleza de Mariluisa, con lo cual refuerza su autoparodia.

A su vez, como si fuesen citados de memoria, los relatos incluyen versos y numerosas imágenes de Darío, apenas modificados. Esto puede verificarse, por ejemplo, en las reiteradas metáforas lumínicas. Así en Carne al sol el "ideal vello, rubio como polvareda de sol" (8); la figura de una de las protagonistas que "rimaba" con "una alegría rubia de sol" (20); la vida de la llanura "rubia de sol" (56); en La carne humillada una "caricia rubia del sol" (31); en Bésame..., una "luz rubia"(14), entre otros, envía a figuras similares en Darío, como por ejemplo "todo el paisaje se veía como envuelto en una polvareda de sol tamizado" ("V Paisaje. Palomas blancas"). En La carne humillada, por su parte, el título del apartado “¡Primavera! ¡Juventud, divino tesoro!”, remite -como resultaría evidente para muchos de sus lectores- al conocido verso de "Canción de Otoño en Primavera". En Historia de una muchachita loca, Pedro, el protagonista, recita: "Era un aire suave de pausados giros. El hada ritmaba sus vuelos" (7) modificando los versos de Prosas profanas ("Era un aire suave, de pausados giros; /el hada Harmonía rimaba sus vuelos"). ${ }^{5}$

Estos ecos de la sensibilidad modernista le habrían permitido a Olivari incluir dentro de una noción de lo literario que no carece de varios modelos, pero en la que Darío ocupa un lugar de relevancia, escenas que de otra forma podría considerar pornográficas en tanto el lenguaje literario conocido para escribir la experiencia erótica estaba tramado por el modernismo. En este sentido, aunque no desarrollaremos este punto, además de los poemas del nicaragüense, los escritos de Azul en los que el narrador refiere sus primeras experiencias amorosas, como "Palomas Blancas y Garzas Morenas", parecen la base que reescriben los relatos de iniciación sexual olivarianos.

\section{Reescrituras}

El modernismo, decíamos, establece para estos relatos -como para muchos otros en ese período- un modelo de lengua literaria y compone además, parte del capital cultural del escritor. En este sentido constituye un dispositivo que posibilita la escritura porque facilita un diccionario y un estilo retórico. Al mismo tiempo, es un punto de partida porque la escritura encuentra su particularidad en el recorrido que la impulsa a desviarse de esa pauta. Es en estos desvíos que Olivari ensaya uno de

${ }^{5}$ Además de las huellas esquemáticamente señaladas, la marca modernista se registra en las comparaciones de las mujeres con diosas griegas (Venus y Diana son las más frecuentes); en las acciones metaforizadas a partir de alusiones mitológicas o clásicas, especialmente para referir al acto sexual, o en las descripciones de los cuerpos a partir de símiles de la mitología (ver, por ejemplo: Carne al sol 32; 62; 2; 34; 48; 57; 59; 45; 53). 
los procedimientos que singularizarán, en la década, su poesía: la reescritura, que no obstante, adquiere distintas formas y proyecciones. Definimos reescritura a partir del uso que observamos en este corpus en particular, esto es, cuando la escritura trabaja con la cita y produce algún tipo de extrañeza con respecto a su sentido o valor o uso establecidos; cuando la fragmenta, la mezcla y la cruza con otras citas y otros materiales y parece olvidar el contexto en el que se inscribía. Es decir, usamos el término reescritura no para citas ilustrativas o respetuosas del texto base, sino para aquellas que sufrieron algún tipo de cambio y apropiación.

En primer lugar, nos ocuparemos de los procedimientos que desacralizan algunos de los parámetros de una lengua literaria investida con los valores del prestigio y de la "alta" cultura. Si el modernismo remite a lo "lujoso", en la escritura de Olivari, también "abarata". Llamamos "abaratamiento" al movimiento que al degradar, rebajar o resituar una referencia, una imagen o un uso retórico determinado, no solamente cuestiona un estilo, sino que interroga lo que podía pensarse como literario y, en estrecha relación con esto, desacraliza una figura de escritor. Estos procedimientos que fueron esbozados en las narraciones realistas se continúan y profundizan en la escritura poética de forma tal que en las narraciones pueden leerse los ensayos de las refutaciones vanguardistas que escribe su poesía. En segundo término, estudiaremos el lugar que Darío ocupa en esta fase del programa olivariano. Puntualmente, seguiremos el modo en que la primera poesía de Olivari trabaja con la obra más divulgada de Darío: a partir de fragmentarla, de escoger sólo algunos de sus componentes y mezclarlos en un nuevo texto, hace del modernismo una de sus condiciones de posibilidad. En tercer lugar, continuando las descripciones previas, estudiaremos la formulación de una poética que se define por contraste con la dariana. Seguiremos esa diferencia en la construcción de un sujeto poético desauratizado que escribe su fracaso y que despoja a su voz de cualquier gesto lírico y remisión a lo sublime.

\section{Abaratar}

En el cuento "La caída", de Carne al sol, puede verse sugerido el inicio de este movimiento: puntualmente, el esbozo de una pregunta que comienza a cuestionar la validez de esas figuras que gozaban de prestigio literario y eran indicio de cultura elevada. Aquí, el narrador interrumpe una ambientación que acumula los recursos retóricos presentes en todo Carne al sol -y por lo tanto, constituye un perfecto ejemplo del estilo hiperliterario al que hicimos referencia- para introducir una aclaración que, sin embargo, interroga sus afirmaciones previas:

en el ambiente madrigalesco de la calle arbolada, cuya suave umbría en la magnificencia plateada de esa luna de Marzo, cobraba un inquietante trasunto de versallesca corte de amor. Juliana no sabía de Versalles y de amor muy poco (27) 
El narrador que se había distanciado del personaje durante todo el cuento, en la última oración del fragmento citado insiste en esa distancia, pero mediante una reflexión que se vuelve sobre el propio relato y señala un desajuste entre la retórica y la representación. El narrador cree que la imagen que empleó dejó de ser adecuada para expresar los sentimientos de esa chica de barrio. Aunque en este caso se trata de una reflexión metaliteraria breve, el procedimiento no es aislado en el conjunto de los escritos de Olivari. Es más, lo que en este fragmento aparece sugerido como una imprevista interrupción de un discurso que se exhibía engolosinado en sus propias formas retóricas, será recurso en escritos posteriores.

Otra forma de este desplazamiento se puede leer en el cuento "Sol de mediodía", donde las huellas modernistas con sus respectivos componentes simbólicos chocan con elementos que resultan ajenos a esa estética:

Al glou-glou del líquido quemando la garganta, respondió un carraspeo que limpió redondamente el gaznate, saltando en un gargajo que entre la tierra y el sol, quedó brillando como una medalla (54)

Aquí, el modo en que el narrador compone las imágenes y comparaciones -el escupitajo que por su reflejo engañosamente parece una medalla- desarticula el gusto o la sensibilidad modernista elaborada en el mismo texto. Pero también interroga los usos presentes en otros pasajes del libro, donde la medalla, por ejemplo, es el símil elegido para describir un bello rostro femenino. Por ejemplo en "La caída", el narrador describe a la protagonista: "de perfil gracioso y cándido en la leve aristocracia de la barbilla, insinuada en un relieve, un poco augusto, de medalla antigua" $(24){ }^{6}$

Con estos mecanismos, Olivari se apropia de imágenes cargadas de resonancias y las abarata, sin que por eso pierdan su capacidad de seguir remitiendo, aunque de un modo desviado y que incorpora la ambigüedad en la remisión, a las retóricas en que fueron pensadas.

Esta operación de abaratamiento del modernismo -apuntada en Carne al sol (1922)- se intensifica y explicita en el relato más paródico de esta etapa, la novela corta ;Bésame en la boca Mariluisa! (1923). Aquí las referencias a los escritos de Darío y la elección de una retórica modernista participan de la parodia de una figura de escritor encarnada (en el sentido de hecha cuerpo, protagonizada y representada tanto por sus rasgos discursivos como gestuales) por el narrador personaje. Éste que compone a un escritor joven y trabajador- describe los elementos del texto que

${ }^{6}$ A su vez, esta imagen recuerda la escritura de Darío en Azul: “A veces, contemplando su perfil, pensaba en una soberbia medalla siracusana, en un rostro de princesa" ("Palomas Blancas y Garzas Morenas”). 
planea escribir con una imagen que condensa ese modo novedoso de relacionarse con la tradición:

Escena: La Grecia ática y perfumada. Una Grecia como se ve en la ilustrada imágen [sic] del monte Athos, en la etiqueta de los cajoncitos de pasas de Corhinto (5)

En este sentido, la imagen puede interpretarse en una dimensión doble. Por un lado, Olivari apelaba a la cultura clásica, pero evidentemente, no como a una referencia prestigiosa y prestigiante; sino para subrayar el efecto contrario: la parodia del personaje y, por lo tanto, su inadecuación. Cuando en su trabajo como empleado el narrador debe escribir números en un libro contable, en cambio tiene un ataque de inspiración y escribe una tragedia en versos, lo que provoca su despido. Pero además, la Grecia posible de imaginar era aquella dibujada en la "etiqueta" de un envase, es decir, un producto publicitario donde la asociación con lo literario constituye un vínculo ya remoto.

Por otra parte, la aclaración también figura a un tipo de lector: el que conoce o identifica a Grecia antes con la imagen comercial -o sea, por su condición de mercancía- que por referencias eruditas a la cultura clásica.

El cruce de esos elementos, a la vez que refuerza la parodia de esta figura de escritor -que no solamente debe trabajar para subsistir, sino que tampoco accede a trabajos vinculados con la escritura o que posean algún signo de prestigio intelectual-, subraya la distancia respecto de la tradición modernista y de una concepción humanista de la cultura. Al mismo tiempo, establece una relación con los lectores del espacio ampliado situándose en una zona social cercana. Es en estos sentidos que se efectúa el abaratamiento de la referencia; pero además, la especificación señala que no sería exclusivamente un procedimiento textual y literario, sino que integra un fenómeno de apropiación que también se estaba produciendo en otras prácticas culturales. ${ }^{7}$

Una enunciación de esta operación, que anticipa los cruces de la escritura vanguardista en la poesía de Olivari, puede encontrarse en Manuel Gálvez, ensayo sobre su obra (1924). Cuando en este libro, que Olivari escribe en colaboración con Lorenzo Stanchina, ambos leen los primeros poemas de Gálvez destacan precisamente la ausencia de esas marcas modernistas que se habían convertido en el lugar común de los escritos epigonales:

${ }^{7}$ Una prueba de apropiaciones por la cultura masiva puede encontrarse en el estudio de Rogers (2008) sobre la revista Caras y Caretas. 
Rompiendo la tradición obligada en aquellos tiempos, no canta este libro a Versalles ideales ni a Trianones de confitería, ni a cantarinas fuentes de oleografía barata; sólo muestra con sencillez el alma pura e ingenua de un poeta que habla de las cosas que conocieron sus ojos (32)

Es decir que la flexión realista defendida en el conjunto de este ensayo, y que en el fragmento se sintetiza en un interés por incorporar a la literatura la propia experiencia del escritor, puede pensarse como uno de los componentes que posibilitó el desplazamiento y la interrogación del modernismo en la literatura rioplatense durante las primeras décadas del siglo XX. La cita subraya los intereses del lector y por tanto, sugiere las preocupaciones del escritor. Ambas cuestiones, junto con las operaciones que Olivari efectúa, confunden -en el sentido de mezclanen el mismo proceso de configuración de una lengua literaria propia, la búsqueda realista con los procedimientos (si se prefiere: incipientes) de la vanguardia. En otras palabras, permiten trazar una línea que a través de Olivari, vincularía la literatura de Gálvez -específicamente su primer libro de poemas Senderos de humildad- con la poesía de la llamada primera vanguardia histórica argentina. Si esta afirmación contradice las tradiciones establecidas por la historia literaria sobre el período ${ }^{8}$ en cambio resulta previsible al considerar el proceso de la cultura hecho de intercambios, diálogos y apropiaciones no siempre explicitados o factibles de reconstruir.

Tal como sugieren estas operaciones de interrogación y abaratamiento, la literatura de Olivari está hecha de mezclas y transformaciones. Combina distintos materiales, los corta, los altera, los descontextualiza y los vuelve a contextualizar, según evidencia la imagen del escritor que situado en la década de 1920, piensa en una Grecia de ilustración publicitaria. Estos son los procedimientos que, a su vez, enlazarán sus escrituras con el corpus de las vanguardias.

\section{Recortar y mezclar}

Las operaciones de transformación que seguimos a través de las reescrituras de un repertorio de textos, imágenes y figuras modernistas proponen, por lo menos, una vuelta más. Paralelamente, Olivari parte de alusiones o citas veladas para desplegar una nueva escritura donde la presencia del texto citado -que puede restringirse a una frase, a la perspectiva de un personaje o al punto de vista de un sujeto poético, a un elemento no desarrollado en una escena, a un conflicto latenterecobra su potencia productiva. En estos escritos, Olivari toma del texto base

\footnotetext{
${ }^{8}$ En este sentido, Sarlo enfatiza esas distancias cuando estudia el ensayo sobre Gálvez de Olivari y Stanchina: "Es difícil pensar en propuestas más diferentes que la de Gálvez y el martinfierrismo, pero imposible encontrar orígenes sociales más parecidos" (Sarlo 1999: 189).
} 
algunos elementos para componer una escena y los desarrolla en una situación sin otros puntos en común con la original más que aquellos que cita. En este sentido, el procedimiento podría emparentarse con el trabajo que realizará un par de años después en su poesía. Allí Olivari mezcla materiales provenientes de diferentes zonas de la cultura en una yuxtaposición similar a la del collage.

¡Bésame en la boca Mariluisa!, permite describir este procedimiento. La historia alude a uno de los textos más difundidos de Darío: "Era un aire suave...". En este caso, Olivari recorta el trío de personajes del poema y su conflicto amoroso: el "abate joven de los madrigales" que disputa el amor de Eulalia con el "vizconde rubio de los desafíos" se corresponderían en el relato con un cura del pueblo, Mariluisa y el escritor Mario Morante. El narrador provee los indicios de la cita cuando nombra insistentemente "abate" al cura, el único rival masculino en el amor de Mariluisa; y al comienzo una prostituta llama "rubio" al protagonista. Pero además, una escena refuerza estas alusiones, a la vez que enfatiza la parodia del narrador: Morante se burla del cura por la blancura y el cuidado de sus manos y aclara: "Son las suyas las manos del abate joven que en el verso de Rubén le dice sonceras[sic] galantes a las marquesas" (32). En este relato en particular, el trabajo con elementos que remiten a los textos de Darío contribuye la construcción paródica de la figura de escritor, además de proponer un dispositivo para la escritura y un uso distanciado del estilo percibido como viejo.

En este entramado iBésame en la boca Mariluisa!, contiene otra mención explícita a Darío que participa en esa elaboración del protagonista. Mientras el narrador pasea de noche por los alrededores de la casa de campo, describe una glorieta que encuentra a su paso: "Era una rústica glorieta [...] haciéndola misteriosa y bella como las glorietas que canta Darío" (23). La referencia podría leerse en relación con dos textos de Darío. Por un lado, en "Era un aire suave" la glorieta permite el encuentro amoroso de Eulalia con el poeta:
la marquesa alegre llegará al boscaje,
boscaje que cubre la amable glorieta
donde han de estrecharla los brazos de un paje, que siendo su paje será su poeta

Al contrario de lo que estos versos sugieren, en ;Bésame en la boca Mariluisa!, cuando el protagonista se acerca a la glorieta, descubre a Mariluisa, su enamorada, en una relación erótica con Fina, la prima.

Por otra parte, en el relato "La ninfa" de $\mathrm{Azul}$, un narrador que emplea un tono familiar al que Olivari utiliza en su novela corta, compone una situación con elementos similares a los de este fragmento. Mientras Darío escribe "Yo vagaba por el parque del castillo"; el narrador de Olivari dice: "Pero aquella noche yo me fui a vagar por los campos". Ambos pasean entre rosas, glicinas y ramajes cuando encuentran la glorieta, pero mientras que en iBésame en la boca Mariluisa! se 
detiene ("oí voces en su interior" (23)), y al espiar descubre a Mariluisa; en Darío sigue de largo porque el ruido que atrae su atención es más lejano ("oí un ruido, allá en lo oscuro de la arboleda, en el estanque"), y también espiando, descubre a las ninfas.

Es decir que Olivari podría haber partido de los relatos y poemas de Darío y seleccionado algunas de sus situaciones, imágenes y figuraciones; pero al mismo tiempo, cuando las escribe se distancia de ellas porque las modifica, resitúa y actualiza para contar la historia, en tono paródico, de una figura de escritor que por seguir el modelo finisecular, no puede insertarse en el espacio literario. En este sentido, aunque parezca contradictorio, la apropiación modernista al mismo tiempo que permite establecer en qué consiste aquello que conviene abandonar porque resulta residual, señala su vigencia y contribuye a la elaboración de lo nuevo.

\section{La construcción de un nuevo tipo de sujeto poético: el fracaso como respuesta}

En los poemas de La amada infiel (1924), las reescrituras de los textos del modernismo -o para decirlo de otro modo, su simultáneo empleo e interrogaciónpromueven un movimiento que, a la vez que reterritorializa y abarata sus tópicos, motivos y figuras, produce la formulación de un nuevo lenguaje que postula a lo vulgar y a un sujeto que habla signado por el fracaso como temas y ejes constructivos. Mientras que el narrador de "Revelación", en Carne al sol, usa el término "vulgar" para descalificar, censurar y subrayar su distancia respecto de los consumos culturales y apropiaciones de los sectores populares, ${ }^{9}$ en el poemario $L a$ amada infiel la valoración cambia, o más bien, deja de usarse para descalificar esos usos y comienza a describir la propia escritura. En otras palabras, los procedimientos de reescritura facilitan el desplazamiento de los tópicos del exotismo y del énfasis en una concepción universalista del amor y de la cultura hacia una literatura situada, es decir, porteña en la década de 1920 y donde el término "vulgar" condensa sus características y condiciones principales. En verdad, los desplazamientos hacia una literatura situada formaban parte de los movimientos que producía mucha de la poesía vanguardista en la época; sin embargo, en Olivari esto se vincula con una reconversión de lo "vulgar" que contesta los valores de la institución literaria dominante, además de singularizar su escritura.

\footnotetext{
${ }^{9}$ Así, por ejemplo, en un fragmento que relata la puesta en escena "aburriendo en tres largos actos..." (Carne al sol 10) de los versos románticos de "Campodrón", el narrador describe los versos como "vulgares y chillones" (11) y el acento del recitado, "ridículo". Más adelante, vuelve a usar el calificativo "vulgar" que aplicaba a los versos, pero sustantivado y en un sentido más abarcador: "Pero él [Julio] no notaba la vulgaridad del espectáculo. Qué iba a notar, si le parecía su voz [la de la mujer], envuelta entre la música disonante de los adjetivos terminados en $<<$ an $>>$ y en $<<$ zon $>>$, la más divina sinfonía! (11).
} 
Estos movimientos pueden seguirse en los poemas "X" $\mathrm{X}$ " $\mathrm{y}$ en "Yo, poeta...", donde el sujeto poético se diferencia del modernista por su posición. Se trata de un sujeto que relata su fracaso porque no logra adecuarse a una ideología estética (es decir: una sensibilidad, valores y modos de percibir el mundo, pero también las formas que estas cuestiones configuran) con la cual, en verdad, ya no se identifica. Ambos poemas componen una secuencia que reescribe "Divagación" de Darío, en principio, desde un punto de vista temático, aunque también a partir de algunos de sus procedimientos. ${ }^{11} \mathrm{Si}$ el poema dariano remite a una concepción universal del amor, a una mujer idealizada y a geografías distantes de las americanas; inversamente, estos poemas proponen un amor desacralizado, sin mistificaciones literarias y situado en un espacio cultural y geográfico irrelevante, degradado desde un punto de vista literario moldeado en el modernismo ("si el paisaje, si el río/ es vulgar como epístola de hortera" ("X")). O, si como en "Yo, poeta...", recurren a los tópicos del exotismo, es para contestarlos desde la parodia y confinarlos a un plano imaginario. Aunque Olivari escribe este tipo de proposiciones en la mayoría de sus poemas, tanto "X" como "Yo, poeta..." (editados en el poemario uno a continuación del otro) además, las tematizan y relacionan de modo más evidente con la cita modernista.

Por un lado, "X" propone una versión anti romántica del poema a la novia cuyo comienzo ("Como quieres que te quiera"), asimismo, es un motivo recurrente en numerosas coplas populares de América y de España. Y "Yo, poeta...", por su parte, presenta a un sujeto que espera conquistar a su amada a través de la literatura:
Para lograrte amada de mi ensueño
en algo ha de valerme la poesía
por ella llegaré a ser tu dueño,
por ella entre mis brazos serás mía.

A su vez, en el extenso poema de Prosas Profanas (1896), con que vinculamos los dos de Olivari, el sujeto poético describe su amor mediante una larga lista de referencias culturales que remiten a Grecia, Roma, Francia, China, Japón y Jerusalén. Si, como dice Montaldo, Darío postula un arte erótico que puede traducirse al "erotismo de las diversas culturas y pasear por las geografías y

${ }^{10}$ El título de este poema condensa la intención humorística y desacralizadora del conjunto: no se trata del décimo poema del libro, pero sí del único numerado. El chiste residiría en que todo poeta conocido o todo libro de poesías, tenía su soneto número X.

${ }^{11}$ Se trata además, del mismo poema que imita Pedro, el protagonista de Historia de una muchachita loca, durante su viaje en barco. En este sentido, en el conjunto de estos relatos abundan las referencias a la literatura modernista también como parte de la composición verosímil de los personajes. 
mitologías desterritorializadas" (Montaldo 1994: 56); Olivari, en cambio, lo reterritorializa. Frente a ese amor universal, que se imagina más allá del tiempo y del espacio concretos porque apela a su vez, a toda la enciclopedia de la cultura de occidente; y ante las exigencias y extravagancias del sujeto poético modernista, ligado a una sensibilidad finisecular y humanista, el sujeto olivariano introduce una serie de diferencias que subrayan su nuevo posicionamiento moderno y vanguardista.

En este sentido, Darío sintetiza el tono y el sentido de "Divagación" en el último cuarteto de endecasílabos:
Ámame así, fatal cosmopolita, universal, inmensa, única, sola $\mathrm{y}$ todas, misteriosa y erudita ámame mar y nube, espuma y ola.

El imperativo y el énfasis en la condición extraordinaria de la amada, de tono festivo en Darío, en cambio, en " $X$ " se transforman en súplica y angustia ante esa amada que por extraña, pareciera volverse desconocida:
Amémonos de cualquier manera.
Acéptame vulgar, contradictorio y vacuo, pero ámame, ámame! que esta angustia de sentirte extraña, de ver como te alejas es un clavo clavado con tus puños en la propia mitad de mi tristeza.

Es decir que si el poema de Olivari comienza con una broma y un verso liviano no solo por su sintaxis, sino porque desdramatiza el tópico amoroso ("Como quieres que te quiera/con un amor heroico a lo bandido")-; termina, sin embargo, con un sujeto poético que manifiesta su incomodidad ante el exotismo de la amada. Pero se trata de un exotismo sugerido por la percepción de la extrañeza ("esta angustia/de sentirte extraña, de ver cómo te alejas"); lo que en cierta forma, lo vuelve un exotismo también reterritorializado. Los dos endecasílabos finales subrayan, entonces, el contraste con el comienzo del poema y proponen afirmativa y seriamente, el punto de vista de este sujeto poético: a través de la metonimia y las palabras elegidas el tono se modifica y no parece posible una lectura en clave irónica o bromista ("es un clavo clavado con tus puños/en la propia mitad de mi tristeza"). El cambio de tono, el contraste abrupto, sugiere la elaboración de un procedimiento que se definirá como rasgo de estas escrituras.

Pero además, cuando Darío describía a la amada con una enumeración que subrayaba al mismo tiempo, su singularidad y su universalidad, y con esa síntesis aludía a algo extraordinario; en " $X$ ", en cambio, el sujeto poético se describe a sí mismo y propone una enumeración que borra lo excepcional y reduce lo complejo a 
la contradicción y al vacío. De hecho, Olivari modifica el tono del imperativo dariano por el de la imploración que enfatiza los sentimientos de frustración y de fracaso. Mientras que en Darío el sujeto poético confía en sus capacidades para atraer a la amada, es decir que cree en la eficacia de su escritura (de hecho, los versos finales anticipan el éxito de la conquista: "Duerme. Yo encenderé los incensarios. /Y junto a mi unicornio cuerno de oro, /tendrán rosas y miel tus dromedarios"); por el contrario, en este poema de Olivari lo exótico se torna extraño y provoca el alejamiento de la mujer que se buscaba conquistar.

A su vez, mientras que en Darío el sujeto poético permanece íntegro y en cambio, varía el ser amado; en "Yo, poeta...", el segundo texto vinculado con "Divagación", se disgrega y transita ficcionalmente distintas identidades. La cláusula "como un", también utilizada por Darío en su poema, introduce cada una de estas posibilidades, continuando la organización estrófica y de poema largo que tiene "Divagación". A medida que describe esas identidades imaginarias ("un califa árabe"; "un vándalo bárbaro"; "un grande de España antiguo"; "un sutil griego academisante"; "un sátrapa persa de ojo sesgado"; etc.), el sujeto poético olivariano desliza bromas ("tu amor será mío, rendido a los altaneros/ mostachos borgoñones, igual que como diz/llevaban insolentes los tres mosqueteros."); observaciones que podrían incomodar a un lector entrenado en la lectura de poemas de amor porque espera en ellos encontrar elogios del ser amado ("para que me correspondas oh! amada ignorante/te iniciaré en los temas del divino Platón."); descripciones de actos crueles, violentos o absurdos, pero verosímiles para el contexto histórico que cada referencia cita:
O como un vándalo bárbaro atada a mis caballos te llevaré por burgos, por feudos y comarcas que incendiaré a tu paso, para que lacayos te sirvan de rodillas todos los monarcas.
O como un grande de España antiguo me iré hacia el Oriente en procura de un bien, para enviarte luego el testimonio exiguo de cien infieles muertos en Jerusalem.

De este modo, en "Yo, poeta" Olivari reescribe en un tono por momentos evidentemente paródico, los tópicos del exotismo. Lejos de presentar, entonces, arquetipos puros, imagina sus particularidades históricas y diferencias culturales; y en esos contextos la amada puede sufrir vejaciones; ser sospechada de infidelidad ("al verte gigolette que así me eres infiel") y amenazada de muerte ("y si me traicionas...con todo sentimiento/recurriré a mi tío, el Borgia, Papa de los venenos"); o presenciar y causar crímenes a pueblos enteros. 
Con todo, el poema también incluye imágenes de matriz modernista que consideradas separadamente del conjunto, no parecen interrogar el modelo. En este sentido podría interpretarse la primera de la serie de estrofas que relatan cómo el sujeto poético imagina la conquista de su amada mediante la literatura:

Como un califa árabe derramaré a tu paso

la mirra y el incienso y el crótalo sonoro

danzarás desnuda cual una flor de raso

en mi alcázar fantástico de pedrería y oro.

Sin embargo, si estos versos se leen siguiendo el orden del poema es posible advertir un relato que se inicia con esta estrofa que formula un homenaje a la amada mediante los recursos modernistas; luego continúa con las estrofas referidas en primer lugar, que sugieren la imposibilidad y las dificultades del sujeto poético para encuadrarse en los parámetros verosímiles establecidos por esas imágenes; y culmina con el yo que habla aclarando cuál era finalmente, el único método de conquista plausible y la naturaleza de su amor. Así, como si volviera a la realidad y dejara atrás las fantasías exóticas dice:

Pero tu amor tendré de esta manera:

conquista entre ironías que he comenzado yo,

con el manoseo canalla, que me tolera

la luz de la sala donde se danza el fox-trop.

Luego la eterna, vulgar, anodina historia, un auto y una calle, y una casa de cita, y yo que para ti soñé conquistar la gloria,...

tristezas de la carne...comadre Afrodita...

La larga enumeración de posibilidades y situaciones finaliza de esta manera, con una explicitación doble: por un lado, el carácter fantasioso, en el sentido de inventado, que tuvo ese recorrido por espacios lejanos; y por otra parte, indica el fracaso del sujeto poético en su intento de utilizar unos recursos aparentemente inadecuados para su amor ("y yo que para ti soñé conquistar la gloria,..."). La historia vulgar, anodina y eterna pareciera, de acuerdo con los elementos que la componen (un auto, una calle, una casa de citas), la historia popular, la del tango y la novela sentimental que de este modo, ingresan al universo poético en contraste con los tópicos exóticos de las estrofas previas, y constituyen así otra de las formas de la interrogación y del abaratamiento cuyo efecto más evidente es el de la desacralización de los contenidos poéticos.

En esta trama, Afrodita no es una cita cultural más: mencionarla en este contexto y calificarla de "comadre" subraya que ya no se trataría de una referencia culta a la diosa del amor mítica. La figura se rebaja y, despojada de connotaciones 
prestigiosas o mejor, lustrosas, pasa a integrar el sistema de sentidos vulgarizados que el poema propone.

La estrofa final sugiere, de hecho, todavía un último énfasis en el fracaso y en la frustración que acrecienta el efecto desacralizador -a nivel cultural y literariobuscado por el conjunto de la poesía olivariana de la década. Se trata, sin duda, de un verso de contenido escandaloso para los valores morales dominantes en el período y provocador, en tanto contesta los parámetros del "buen gusto", el estereotipo moral sobre la mujer, o el decoro que se esperaba de la poesía escrita en norma culta:

$\mathrm{Y}$ en la alcoba tibia de sugestiones rica

de los sensualismos el más torpe elijo

para que mañana digas, oh modernista chica!

gracias te doy poeta, que no me has hecho un hijo!

Los versos condensan -en la imagen que alude la interrupción del coito- el fracaso del sujeto poético que se había propuesto conquistar el amor de una mujer a través de la literatura -específicamente de "la poesía"-, pero en el camino advierte que esos recursos ya no le sirven porque la historia que relata, o el espacio en el que se sitúa, pareciera adecuarse mejor a la "clásica" y "anodina", ambientada en una calle porteña, antes que a la fantástica propuesta por el modernismo. Es decir que, si por un lado la estrofa participa del cuestionamiento del amor romántico y de sus protocolos, así como de su explotación literaria; también parece responder desde la diferencia a la fecundidad modernista: "cuando una musa te dé un hijo, queden las otras ocho encinta", escribía Darío. Escribir lo vulgar, lo anodino, lo pobre, la frustración y el fracaso (junto con lo escaso y lo poco), podrían leerse entonces, como búsquedas y hallazgos en este proceso de producción de una lengua literaria. Un proceso que en varios de sus movimientos se encuentra traccionado por la necesidad de diferenciarse del modernismo, y no solamente porque era una estética previa sino porque era la predominante en la cultura del momento. Pero según leímos, se trata de una diferencia que, pareciera, debe pensarse en términos no exclusivamente estéticos, sino en relación con las experiencias que en las escrituras se configuran. ${ }^{12}$

${ }^{12}$ El conjunto de estas afirmaciones que leen en la escritura literaria un proceso cultural más amplio se inspiran en los trabajos de Raymond Williams, para quien el lenguaje es una práctica material constitutiva "a la vez individual y social [...] histórica y socialmente constituyente" (2000: 58. Véase en este libro el apartado "Lenguaje" (32-58).). En esta línea, pensamos la forma como "un proceso social" que "se convierte en un producto social" (Williams 2000: 215). Así, el recorrido que sigue la lengua literaria que Olivari elabora se 
Una cuestión más, aún, podría apuntarse: resulta significativo, de acuerdo con lo que intentamos leer, que en el contexto del poema el sujeto poético califique a la mujer de "modernista" -como si se estuviese refiriendo al movimiento estético, o a la literatura- en lugar de "moderna", lo usual y esperable según la lógica de la frase. Que la musa de "Yo, poeta..." sea, entonces, una musa modernista ("oh modernista chica!") y que al contrario de las prolíficas musas darianas, no engendre hijos, enfatiza como señalamos, el fracaso del sujeto poético, pero en tanto la descendencia modernista se interrumpe. En este sentido, este poema podría pensarse como una presentación y formulación del modo en que se construye ese "Yo, poeta...". Esto es: a partir del modernismo y ensayando su escritura hasta comprobar que es solo desplazándose de la misma y declarando su ineficacia como puede seguir escribiendo.

Como señalamos, esta reterritorialización en relación con el modernismo acompaña uno de los movimientos que realiza la escritura de Olivari: el encuentro en lo desprestigiado, lo abaratado, lo vulgarizado, lo pobre y otros sentidos afines, las formas novedosas de su poética. Además de las apropiaciones señaladas, en el conjunto de su poesía del período puede seguirse el alejamiento de los principales parámetros sobre lo poético que dominaban en lengua española, tanto en el nivel retórico y figurativo como prosódico. Si para Darío la musicalidad era una cualidad poética buscada, ${ }^{13}$ en cambio Olivari propone una desmusicalización de su poesía a partir del ripio, de una métrica irregular y de cortes abruptos del ritmo. De esta forma, en el mismo movimiento que busca separarse de la estética dariana, la poesía de Olivari despliega su principal diferencia: se postula pobre en oposición a las riquezas y abundancias de los textos modernistas. Pobre en sonoridad, y también en el imaginario que construyen las referencias. En lugar de un "tropel vibrante de fuerza y harmonía", como escribía Darío, o del "tropel sonoro" que hacía temblar la "Isla de Oro", en ese mismo poema; estas poesías de Olivari configuran un sujeto poético desauratizado que como explicamos, es a partir del modernismo que construye su divergencia.

Si hasta el momento, ciertas apropiaciones de la estética modernista circulaban en las zonas ampliadas de la cultura, Olivari retoma esos valores y procedimientos y los reescribe como poesía de vanguardia. Dicho en otro sentido, en la necesidad de

inscribe en un cambio cultural donde emergían nuevos modos de decir que, entre otras cuestiones, minaban el ideal de una lengua única e incontaminada.

${ }^{13}$ Darío comienza el "Coloquio de los centauros" (Prosas Profanas 1896) con estos conocidos versos que describen la lengua poética modernista: "En la isla en que detiene su esquife el argonauta/del inmortal Ensueño, donde la eterna pauta/de las eternas liras se escucha -isla de oro/ en que el tritón elige su caracol sonoro/ y la sirena blanca va a ver el sol-, un día/se oye el tropel vibrante de fuerza y de harmonía” (200). 
diferenciarse de los tópicos del modernismo, estas escrituras producen un movimiento que hace de lo "vulgar" un posible literario y que por supuesto, tiende a la desacralización poética.

Pero además, si hubiese que describir en qué consiste ese "vulgar", habría que incluir al modernismo - a su divulgación en los años de 1920-; contradicción de la cual dan cuenta los poemas porque como resulta evidente, acá donde leemos una operación de refutación modernista, muchos lectores encontraron una mala imitación de Darío.

En suma, leer estas operaciones con la escritura modernista permite comprender uno de los desplazamientos más potentes que en los años de 1920, realiza la poesía de Olivari y que inscribe su literatura en el corpus de las vanguardias.

\section{BIBLIOGRAFÍA}

BOURDIEU, Pierre.

1995 Las reglas del arte. Génesis y estructura del campo literario. Barcelona: Anagrama.

BÜRGER, Peter.

1987 [1974] Teoría de la vanguardia. Barcelona: Península.

DARÍO, Rubén.

1948 Obras completas. Buenos Aires: Anaconda.

DERRIDA, Jacques.

1994 Mal de archivo. Una impresión freudiana. Madrid: Trota.

MONTALDO, Graciela.

1994 La sensibilidad amenazada. Fin de siglo y modernismo. Rosario: Beatriz Viterbo.

MUSCHIETTI, Delfina.

2009 "Oliverio Girondo y el giro de la tradición", en Celina Manzoni (directora), Noé Jitrik (ed.), Historia crítica de la literatura: rupturas. Buenos Aires: Emecé Editores, vol. 7, pp. 121-145.

OLIVARI, Nicolás.

1922a Carne al sol. Buenos Aires: Tor.

1922b La carne humillada. Buenos Aires: La Biblioteca de bolsillo.

1923a iBésame en la boca Mariluisa! Ave venus fisica. Buenos Aires: La Novela de Bolsillo.

1923b Historia de una muchachita loca. Buenos Aires: La Novela Humana, Ediciones Zola.

1924 La amada infiel. Buenos Aires: Modesto H. Alvarez.

1926 La musa de la mala pata. Buenos Aires: Martín Fierro.

1929 El gato escaldado. Buenos Aires: Manuel Gleizer. 
OLIVARI, Nicolás y Lorenzo STANCHINA.

1924 Manuel Gálvez, ensayo sobre su obra. Buenos Aires: Agencia General de Librería y Publicaciones.

PORRÚA, Ana.

2007 "La revista Martín Fierro (1924-1927): una vanguardia en proceso", en Gloria Chicote y Miguel Dalmaroni (eds.). El vendaval de lo nuevo. Literatura y cultura en la Argentina Moderna entre España y América Latina (1880-1930). Rosario: Beatriz Viterbo Editora, pp. 129-148.

PRIETO, Adolfo.

1986 "Prólogo", en Roberto Arlt. Los siete locos. Los lanzallamas. Buenos Aires: Biblioteca Ayacucho, pp. IX-XXXIII.

PRIETO, Martín.

2006 Breve historia de la literatura argentina. Buenos Aires: Taurus.

ROGERS, Geraldine.

2008 Caras y Caretas:cultura, política y espectáculo en los inicios del siglo XX argentino. La Plata: Edulp.

SARLO, Beatriz.

1980 "La poesía postmodernista", en Historia Crítica de la Literatura Argentina. Buenos Aires: Centro Editor de América Latina, vol. 47, pp. 97-120.

2004 [1985] El imperio de los sentimientos. Buenos Aires: Grupo Editorial Norma.

1999 Una modernidad periférica: Buenos Aires 1920 y 1930. Buenos Aires: Nueva Visión.

WILLIAMS, Raymond.

2000 [1977] Marxismo y literatura. 2. Barcelona: Península.

ZANETTI, Susana.

1997 Las cenizas de la huella. Rosario: Beatriz Viterbo. 